\title{
Analisis Pengaruh Karakteristik Individu, Karakteristik Organisasi dan Karakteristik Pekerjaan Terhadap Kepuasan Kerja Pegawai /Guru SUPM Negeri Pariaman
}

\author{
Yernawilis*, A.Noesyirwan, Wirawan, Harisjon \\ Politeknik Kelautan dan Perikanan Pariaman \\ yernawilis.supmn@gmail.com
}

\begin{abstract}
This study aims to determine the effect of individual characteristics, organizational characteristics and job characteristics on job satisfaction of employees / teachers of SUPM Negeri Pariaman. This type of research is a causative quantitative research. The sample used was 90 respondents. The data analysis technique used in this research is multiple linear regression, with the help of the SPSS version 16 program. Based on the statistical analysis used, the results are: 1) individual characteristics have no effect on job satisfaction of employees / teachers of SUPM Negeri Pariaman, 2) organizational characteristics have a significant effect on job satisfaction of SUPM Negeri Pariaman employees / teachers, and 3) job characteristics have a significant effect on job satisfaction of SUPM Negeri Pariaman teachers. The contribution value of the influence of individual characteristics, organizational characteristics and job characteristics on job satisfaction is $53.8 \%$, while the remaining $46.2 \%$ is influenced by other variables not included in this study.
\end{abstract}

Keyword: IndividualCharacteristics, and organizationalcharacteristics of JobCharacteristics of job satisfaction

\section{Pendahuluan}

Hasil kerja pada tingkat individu sangat dipengaruhi oleh kepuasan kerja individu. Kepuasan kerja merupakan pernyataan emosi positif hasil dari evaluasi atau penilaian tentang pengalaman kerja seseorang (Liu dan Liping: 2011).Tingkat Kepuasan kerja dapat dijelaskan oleh beberapa faktor diantaranya adalah promosi yang adil, pendapatan, rekan kerja, gaya kepemimpinan dan karakteristik pekerjaan.

Kepuasan kerja merupakan topik penting dalam manajemen sumberdaya manusia. Tujuan manajemen sumberdaya manusia dalam mengelola SDM adalah untuk meningkatkan kepuasan kerjaguru dan karyawan. Kepuasan kerja sangat penting merupakan atribut penting dalam literatur SDM karena kepuasan kerja berdampak terhadap banyak faktor seperti kinerja, produktivitas, keinginan keluar dari organisasi (intention to exit) dan lain-lain. Oleh sebab itu kepuasan kerja merupakan salah topik sentral padal iteratur manajemen sumber daya manusia.

Seperti yang di utarakan diatas bahwa kepuasan kerja berdampak terhadap hasil kerja, seperti kinerja. Kinerja pegawai pemerintah banyak menjadi topik di beberapa majalah dan Koran. Abubakar (2011) menyampaikan bahwa PNS masih bermasalah dengan kinerjanya sehingga diperlukan aturan baru untuk mengenjot kinerja PNS. Bahkan Menteri PAN juga merencanakan untuk mentes ulang kompetensi PNS yang telah ada karena rendahnya kinerja PNS tersebut (Vivanews, 2012).

Indonesia menganut asas desentralisasi dalam penyelengaraan pemerintahan, yaitu adanya pelimpahan wewenang dari organisasi tingkat atas kepada tingkat bawahnya secara hirarkis. Daerah memiliki kewenangan membuat kebijakan daerah untuk memberi pelayanan, peningkatan peran serta, prakarsa, dan pemberdayaan masyarakat yang bertujuan pada peningkatan kesejahteraan rakyat. Tujuan tersebut dapat terwujud salah satunya tentu dengan perubahan sistem birokrasi yang benar-benar pada masyarakat. Seiring dengan prinsip itu penyelenggaraan otonomi daerah harus selalu berorientasi pada peningkatan kesejahteraan masyarakat dengan selalu memperhatikan kepentingan dan aspirasi yang tumbuh dalam masyarakat. Selanjutnya pertengahan 
Tahun 2007 menjadi babak baru bagi penataan kelembagaan daerah di Indonesia secara umum dan Kota Pariaman khususnya. Hal ini karena dikeluarkanya Peraturan Pemerintah No. 41 Tahun 2007 (PP 41/2007) tentang Organisasi Perangkat Daerah yang menggantikan peraturan sebelumnya (PP 8/2003) mengamanatkan beberapa butir perubahan yang harus segera direspon oleh daerah bila tidak menginginkan kesulitan dalam administrasi penganggaran dengan pemerintah pusat. Peraturan Pemerintah ini pada prinsipnya dimaksudkan untuk memberikan arah dan pedoman yang jelas kepada daerah dalam menata organisasi yang efisien, efektif, dan rasional sesuai dengan kebutuhan dan kemampuan daerah masing-masing serta adanya koordinasi, integrasi, sinkronisasi dan simplifikasi serta komunikasi kelembagaan antara pusat dan daerah. Tingkat kepuasan pegawai dan guru SUPM Negeri Pariaman merupakan ujung tombak bagi keberhasilan suatu organisasi dan kepuasan kerja merupakan salah satu faktor yang perlu diperhatikan dalam pertumbuhan dan perkembangan suatu organisasi. Pegawai dan guru yang menyukai pekerjaannya adalah salah satu wujud nyata kepuasan kerja. Melihat kondisi ini, maka tingkat kepuasan guru dan pegawai mutlak perlu diperhatikan agar lebih tanggap terhadap pekerjaannya.

Berdasarkan Peraturan Pemerintah Republik Indonesia yaitu undan-undang No 20 tahun 2003 tentang system pendidikan Nasional dan Undang-Undang nomor 31, tentang Perikanan sebagaimana telah diubah dalam Undang-Undang nomor 45 tahun 2009 dihadapkan pada beberapa kendala mendasar. Pertama, ketersediaan anggaran yang sangat terbatas. Hal ini sering kali menyulitkan, terutama dalam hal alokasi anggaran. Kedua, kurangnya SDM guru yang berpengalaman untuk ditempatkan mengisi jabatan yang ada karena banyak terjadi peningkatan status kelembagaan, pembentukan instansi-instansi baru, yakni berdasarkan beberap hal tersebut diatas, pusat pendidikan Kelautan dan Perikanan bertangguing jawab dalam mengembagkan kurikulum berbasasis kompestensi dengan pendekatan pembelajaran Teaching Factory dengan demikian diharap pada guru yang sehingga peserta didik memiliki profesionaslisme, memiliki etos kerja yang tinggi, disiplin dan berbudaya.

Lingkup pendidikan disekolah SUPM negeri Pariaman yang ada di pemerintahan pusat dan berada didaerah memiliki dari beberapa bidang program studi diantaranya Bidang Penangkapan Ikan, Bidang Mesin Perikanan, Bidang budidaya perikanan, guru yang mengajar sesuai Kelompok Jabatan Fungsional.

Pada sekolah usaha perikanan menengah masih ditemukan dalam penempatan posisi jabatan tidak sesuai dengan kemampuan dan latar belakang pendidikan. Pekerjaan yang menuntut kecakapan yang lebih tinggi dari pada yang dimiliki tenaga kerja, atau tuntutan pribadi yang tidak dapat dipenuhi tenaga kerja akan menimbulkan frustasi dan akhirnya dapat menimbulkan ketidak puasan kerja.

Demikian halnya dengan guru SUPM Pariaman terlihat beberapa fenomena, masih ditemukannya penempatan guru tidak sesuai dengan keahliannya sehingga guru bekerja dan tambahan kerja pada instansi tidak maksimal. Disamping itu adanya suatu pekerjaan pada beberapa sub bidang yang pekerjaannya tumpang tindih dengan sub bidang lain, sehingga perlu dilakukan koordinasi dan integrasi dalam penyelesaian pekerjaan tersebut. Kemudian ada sub bidang/seksi yang kurang tanggap terhadap tugas-tugas yang harus diselesaikan karena bisa jadi tugas tersebut berkaitan dengan tugas yang lain. Hal ini menghambat penyelesaian tugas secara keseleuruhan. Akibatnya akan berimplikasi terhadap kinerja organisasi dan individu yang pada akhirnya berdampak terfhadap kepuasan kerja pegawai secara keseluruhan.

Penelitian tentang kepuasan kerja telah banyak dilakukan oleh peneliti sebelumnya. Penelitian ini merupakan replikasi dan modifikasi dari penelitian Sudarsono (2008) mengadakan penelitian untuk mengetahui pengaruh karakteristik pekerjaan dan karakteristik organisasi terhadap kepuasan kerja pegawai pada puskesmas kecamatan sumbermanjing wetan di malang. Sedangkan Hariri,dkk (2004) melakukan penelitian bertujuan untuk mengetahui pengaruh perbedaan individu, karakteristik pekerjaan dan praktik organisasi terhadap kepuasan kerja karyawan. Soenadji Dkk (2003) melakukan penelitian tentang Untuk pengaruh karakteristik individu, iklim organisasi dan komunikasi terhadap kepuasan kerja Karyawan Pada Jasa Tirta. Boy (2009) melakukan penelitian tentang Hubungan karakteristik individu, kompensasi dan iklim kerja dengan kepuasan kerja dosen 
di Politeknik Kesehatan Jambi. Umar (2006) melakukan penelitian tentang pengaruh faktor budaya organisasi, program diklat, dan motivasi kerja terhadap kinerja karyawan dan kepuasan kerja karyawan pada PT Bank Riau. Karyawan (2010) melakukan penelitian tentang pengaruh desain pekerjaan terhadap kepuasan kerja pada Badan Koordinasi Penanaman Modal Provinsi Nusa Tenggara Barat.

\section{Metodologi Penelitian}

Jenis penelitian adalah penelitian kuantitatif yang bersifat kausatif. Populasi dalam penelitian ini adalah seluruh Pegawai dan Guru SUPM Negeri Pariaman yang bekerja pada sekolah SUPN Negeri Pariaman, yang mana jumlah populasinya 90 orang, dimana teknik sampel yag digunakan dengan metode sensus yaitu seluruh populasi dijadikan sampel.Sampel yang digunakan adalah sebanyak 90 responden. Teknik analisis data yang digunakan dalam penelitian ini adalah regresi linear bergandadengan bantuan program SPSS versi 16.

\section{Hasil dan Pembahasan}

Table 1 Regresi dan Uji Hipotesis

\begin{tabular}{|c|c|c|c|c|c|c|c|}
\hline & \multirow[t]{2}{*}{ Model } & \multicolumn{2}{|c|}{$\begin{array}{c}\text { Unstandardized } \\
\text { Coefficients }\end{array}$} & \multirow{2}{*}{$\begin{array}{c}\begin{array}{r}\text { Standardized } \\
\text { Coefficients }\end{array} \\
\text { Beta }\end{array}$} & \multirow[t]{2}{*}{$\mathrm{T}$} & \multirow[t]{2}{*}{ Signifikan. } & \multirow[t]{2}{*}{ Alpha } \\
\hline & & B & Std. Error & & & & \\
\hline \multirow[t]{4}{*}{1} & (Constant) & 21.180 & 6.228 & & 3.401 & 0,001 & \\
\hline & $\mathrm{X} 1$ & 0,259 & 0,162 & 0,148 & 1.602 & 0,113 & $15 \%$ \\
\hline & $\mathrm{X} 2$ & 1.066 & 0,151 & 0,601 & 7.066 & 0,000 & $5 \%$ \\
\hline & $\mathrm{X} 3$ & 0,426 & 0,107 & 0,353 & 3.990 & 0,000 & $5 \%$ \\
\hline
\end{tabular}

Persamaan regresi berdasarkan Tabel 1, di atas adalah :

\section{$\mathrm{Y}=21.180+0.259 \mathrm{X} 1+1.066 \mathrm{X} 2+0.426 \mathrm{X} 3$}

0,426X3 adalah arah pengaruh karateristik pekerjaan (X3) terhadap kepuasan guru dan pegawai. Arah positif, artinya jika karakteristik pekerjaan ditingkat 1 satuan bobot, maka kepuasan pegawai dan guru juga meningkat, demikian sebaliknya.

\subsection{Pengaruh Karakteristik Individu Terhadap Kepuasan Pegawai / guru}

Berdasarkan hasil uji hipotesis variabel karakteristik individu dengan nilai signifikan $0,113>0.05$. Hipotesis 1 yaitu karakteristik individu berpengaruh signifikan terhadap kepuasan kerja Pegawai dan Guru SUPM Negeri Pariaman ditolak. Hal ini terlihat bahwa nilai probalitasnya (signifikan) besar dari 0.05 . Berarti karakteristik Individu yang dimiliki pegawai tidak begitu diperhitungkan untuk kepuasan kerja pegawai Dinas pertanian Kota Pariaman. Penelitian ini mendukung hasil penelitian Boy (2009) mengemukakan kepuasan kerja dosen di politeknik kesehatan jambi sebagaian besar berada pada kategori sedang dan tidak terdapat hubungan yang bermakna antara karakteristik individu terhadap kepuasan kerja dosen politeknik kesehatan jambi. Hipotesis penelitian ini ditolak dan tidak sejalan dengan hasil penelitian Hariri (2004) dan Akbar (2009) yang mengemukakan perbedaan individu berpengaruh signifikannifikan terhadap kepuasan kerja karyawan. Ketidaksesuaian ini disebabkan oleh perbedaan dimensi-dimensi yang membentuk variabel Karakteristik individu, tempat, objek, lokasi penelitian, sumber data, karakteristik responden. Dihubungkan dengan indikator karakteristik Individu dalam penelitian ini, 
semakin tinggi keahlian pegawai terhadap pekerjaannya, semakin baik nilai, sikap dan minat pegawai terhadap pekerjaan maka kepuasan pegawai meningkat, namun sumbangan dalam penelitian ini sangat kecil.

\subsection{Pengaruh Karakteristik Organisasi Terhadap Kepuasan Pegawai dan guru}

Berdasarkan hasil uji hipotesis variabel karakteristik organisasi (X2) dengan nilai signifikan $0,000<0.05$. Hipotesis 2 yaitu karakteristik organisasi berpengaruh signifikanfikan terhadap kepuasan kerja Pegawai dan Guru SUPM Negeri Pariaman diterima. bila karakteristik organisasi yang dimiliki guru dan pegawai sesuai, maka kepuasan kerja pegawai semakin tinggi. Sebaliknya, karakteristik organisasi yang dimiliki pegawai dan guru tidak sesuai, maka kepuasan kerja pegawai dan guru akan menurun. Berarti apabila prilaku pimpinan sesuai, dan didukung oleh lingkungan yang memadai, maka kepuasan kerja akanmeningkat.

Hasil penelitian juga mendukung penelitian Subyantoro (2009) karakteristk organisasi berpengaruh signifikannifikan atau negative terhadap kepuasan kerjas. Selanjutnya Sudrsono (2010) yang menyatakan bahwa karakteristik organisasi yang terdiri dari prilaku pemimpin dan lingkungan berpengaruhsignifikanterhadap kepuasan kerja.

Menurut Toha (dalam Sudarsono 2008) Kepemimpinan merupakan variabel yang harus dipertimbangkan karena dianggap mempunyai pengaruh terhadap kepuasan kerja. Kepemimpinan atau kepala sebagai kemampuan untuk mempengaruhi orang lain supaya berbuat mempunyai peranan yang lebih besar dalam kehidupan organisasi. Sementara itu perilaku yang digunakan oleh seseorang pada saat orang tersebut berusaha mempengaruhi prilaku orang lain.Dengan demikian keberhasilan seseorang pemimpin tergantung pada perilaku pemimpin. Oleh karena itu, kepemimpinan mempergunakan perilaku menghargai, membangun kerja sama, mendorong semangat kerja dan menolong bawahan untuk mencapai tujuan, maka akan dapat meningkatkan kepuasan kerja bawahan. Pemimpin yang sukses adalah yang mampu untuk mengantisipasi perubahan dan sekuat tenaga memanfaatkan kesempatan, memotivasi pengikut untuk mencapai produktivitas yang lebih tinggi, mengkoreksi kinerja yang buruk dan mendorong organisasi mencapai tujuan (Sudarsono 2008).

\subsection{Pengaruh Karakteristik Pekerjaan Terhadap Kepuasan Pegawai / guru}

Hasi studi ini menunjukan bahwa hipotesis yang menyatakan, karakteristik pekerjaan berpengaruh signifikannifikan terhadap kepuasan pegawai terbukti dan diterima. Hal ini terlihat dari uji hipotesis variabel karakteristik pekerjaan (X3) diperoleh nilai signifikan $0,000<0.05$, memberikan makna tentang pengaruh variable karakteristik pekerjaan (X3) terhadap kepuasan Kerja (Y). dalam hal ini, bila karakteristik pekerjaan yang dimiliki pegawai sesuai, maka kepuasan kerja pegawai semakin tinggi. Sebaliknya, karakteristik pekerjaan yang dimiliki pegawai tidak sesuai, maka kepuasan kerja pegawai akan menurun. Berarti semakin sesuai variasi tugas, otonomi pekerjaan, identitas tugas, umpan balik dan pentingnya tugas yang dimiliki pegawai sehingga mampu menyelesaikan tugas-tugas dengan baik, maka kepuasan kerja akan meningkat.

Teori ini berusaha menggambarkan karakteristik pekerjaan mempengaruhi kepuasan kerja Robins (dalam Hariri 2004) lebih menegaskan bahwa kepuasan kerja dipengaruhi beberapa factor dan salah satunya adalah pekerjaan yang menantang. Pegawai cendrung menyukai pekerjaan-pekerjaan yang memberikan kesempatan untuk menggunakan keterampilan dan kemampuan mereka dan menawarkan beragam tugas, kebebebasan dan umpan balik mengenai betapa baik mereka mengerjakanya. 
Hasil pengujian ini juga mendukung pendapat Sudrsono (2010) yang menyatakan bahwa karakteristik pekerjaan yang terdiri dari variasi keterampilan, identitas tugas, otonomi, umpan balik berpengaruh signifikannifikan terhadap kepuasan kerja.

Selanjutnya Wither dalam Hariri (2004) menyatakan bahwa bila pekerjaan tidak atau kurang memiliki identitas, maka para karyawan akan kurang bertanggung jawab dan kurang bangga dengan hasilnya. Ini berarti kontribusi mereka kurang tampak dan berakibat pada penurunan kepuasan kerja.Dalam penelitian ini kepuasan pegawai di pengaruhi oleh karakteristik pekerjaan pegawai. Untuk meningkatkan kepuasan kerja pegawai, pihak manajemen dapat memperhatikan hal-hal yang mempengaruhi karakteristik pekerjaan melalui variasi tugas, otonomi pekerjaan, identitas tugas, umpan balik dan pentingnya tugas. Keterampilan diperlukan untuk melakukan pekerjaan.Makin banyak ragam keterampilan yang digunakan, makin kurang membosankan pekerjaan (Munandar, 2001: 357). Otonomi merupakan ruang lingkup dimana pekerjaan memungkinkan seseorang individu untuk mendapatkan kebebasan, kemerdekaan, dan keleluasaan baik dalam penjadwalan maupun menentukan prosedur yang digunakan dalam menyelesaikan pekerjaan (Hackman dan Oldham: 1980). Umpan balik adalah ruang lingkup dimana seseorang individu menerima informasi yang langsung dan jelas mengenai seberapa efektif ia melaksanakan pekerjaan. Umpan balik ini bisa diberikansecara rutin, atau ketika ada kejadian khusus yang efeknya signifikannifikan bagi organisasi (Donovan 2001). Karekateristik pekerjaan seorang pegawai terlihat pada desain pekerjaan seorang pegawai. Desain pekerjaan menentukan bagaimana pekerjaan dilakukan, oleh karena itu sangat mempengaruhi perasaan pegawai terhadap sebuah pekerjaan, seberapa pengambilan keputusan yang dibuat oleh pegawai kepada, pekerjaannya, dan seberapa banyak tugas yang harus dirampung oleh pegawai. Karakteristik pekerjaan merupakan pendekatan yang lebih mutakhir dari merancang pekerjaan dan merupakan pengembangan terhadap pengayaan pekerjaan dimana berusaha menjelaskan situasi dan merancang pekerjaan efektif bagi pegawai dan guru di SUPM negeri Pariaman.

\section{4. kesimpulan}

Setelah dianalisa dan dilakukan pembahasan terhadap data yang telah diperoleh, maka hasil penelitian ini dapat diambil kesimpulan sebagai berikut:

1. Karakteristik individudengan nilai signifikan. 0,113>0.05. Hipotesis1 yaitu karakteristik individu berpengaruh signifikan terhadap kepuasan kerja Pegawai /guru supm negeri Pariaman ditolak.

2. Karakteristik organisasi (X2) dengan nilai signifikan $0.000<0.05$. Hipotesis 2 yaitu karakteristik organisasi berpengaruh signifikan terhadap kepuasan kerja Pegawai guru supm negeriPariaman diterima.

3. Karakteristik pekerjaan berpengaruh signifikan terhadap kepuasan pegawai /guru terbukti dan diterima. Hal ini terlihat dari uji hipotesis variable karakteristik pekerjaan (X3) diperoleh nilai signifikan $0.000<0.05$, memberikan makna tentang pengaruh variabel karakteristik pekerjaan (X3) terhadap kepuasan Kerja (Y). 


\section{DAFTAR PUSTAKA}

[1] H Abu Bakar, A. (2011). Pemerintah Siapkan Aturan Soal PNS, vivanews, diperoleh dari http :/life.viva.co.id, diakses tanggal 22 Oktober 2012.

[2] Arikunto, Suharsimi, (2002). Prosedur Penelitian, Suatu Pendekatan Praktek. Jakarta: PT. Rineka Cipta.

[3] _ (1993).Manjemen Penelitian. Jakarta: PT. Raja Grafindo. Persada.

[4] Arep, Ishakdan Hendri Tanjung.2003. Manajemen Sumber Daya Manusia. Jakarta: Universitas Trisakti.

[5] As’ad. 2003. Psikologi Industri Seri Ilmu Sumber Daya Manusia. Liberty, Yogyakarta.

[6] Anoraga. 2004. Pengantar Bisnis Modern. Jakarta: P.T. Dunia Pustaka.

[7] Bambang Wahyudi. (2002). Manajemen Sumber Daya Manusia. Sulita, Bandung.

[8] Boy, Hendri (2009) Hubungan Karakteristik Individu, Kompensasi Dan Iklim Kerja Dengan Kepuasan Kerja Dosen Di Politeknik Kesehatan Jambi.

[9] Chen, W, S., I. Kimiko, T. Kiyoshi, and T. Yuki. 2003. Analysis of The Food Consumption of Japanese Households. FAO Economic and Development Paper. Food and Agriculture Organization of The United Nations, Rome.

[10] Dessler Garry. (2007). Manajemen Sumber Daya Manusia. Jilid 2. Edisi Kesepuluh. PT.Indeks. Jakarta.

[11] Ghozali, Imam 2005. Analisis Multivariate Dengan Program SPSS. Semarang: Badan Penerbit Universitas Diponegoro.

[12] Gibson, James L., Jhon M. Ivancevich dan James H. Donnelly Jr., 2000. Organizations, MecGraw-Hill International, Boston.

[13] Griffin, Ricky, W. and Ronald J. Ebert (2002). Business. $6^{\text {th }}$ Ed. Prentice Hull International, Inc.

[14] Handoko, H, 1998, Manajemen Personalia Dan Sumber Daya Manusia, Edisi 2,. BBPE, Yokyakarta.

[15] , (1999). Manajemen. Edisi ke-2, BPFE, Yogyakarta.

[16] Hariri A.P, Afwan, dkk. (2004). Pengaruh Perbedaan Individu, Karakteristik Pekerjaan Dan Praktik Organisasi Terhadap Kepuasan Kerja Karyawan.Universitas Brawijawa : Malang.

[17] Harsey, pawl, Kenneth H Blancard. (1986). Manajemen Perilaku Organisasi; Pemberdayaan Sumber Daya Manusia. Terjemahan, Edisi 4, Erlangga, Jakarta.

[18] Hasibuan, Malayu $\quad$ S.P. $2005 . \quad$ Manajemen $\quad$ Sumber Manusia, Edisi Revisi. Bumi Aksara, Jakarta.

[19] _. (2000). Manajemen Sumber Daya Manusia. Bumi Aksara, Jakarta.

[20] Irianto, J., (2001), Isu-Isu Strategis Pengembangan Sumber Daya Manusia, Insan Cendekia. Surabaya.

[21] Herujito, Y. M. (2001). Dasar-dasar Manajemen, Grasindo, Jakarta.

[22] Karyawan, I Nyoman (2010) Pengaruh Desain Pekerjaan Terhadap Kepuasan Kerja Pada Badan Koordinasi Penanaman Modal Provinsi Nusa Tenggara Barat.

[23] Kreitner \& Kinicki. (2003) Perilaku Organisasi (Buku Satu), Jakarta: Salemba Empat.

[24] Liu, B-C Dan Lingping T.T (2011) Does The Love Of Many Moderate Relationship Between Public service Motivation and Job Satisfaction? The case of chinese profesional In Public sector, Public Administration Review, 718-727.

[25] Mardiana, Tri. (2005). Pengaruh Karakteristik Indidvidu, Karakteristik Pekerjaan dan Pengalaman Kerja terhadap Komitmen Kerja. Journal fromJTPTUMS, Telaah Bisnis Volume 5 No 2 Desember 2004.

[26] Noe, Raymond A, Hollenbeck, J.R, Gerhart, B, Wright, P.M. (2003). Human Resources Management: Gaining a Competitive Advantage, 4 `h edition, McGraw-Hill/Irwin, New York.

[27] Subyantoro, Arief (2009). Karakteristik Individu, Karakteristik Pekerjaan, Karakteristik Organisasi Dan Kepuasan Kerja Pengurus Dimediasi Oleh Motivasi Kerja. Yogyakarta : FE UPN Peteran.

[28] Sudarsono (2008).Pengaruh Karakteristik Pekerjaan dan Karakteristik Organisasi Terhadap Kepuasan Kerja Pegawai Pada Puskesmas Kecamatan Sumbermanjing Wetan di Malang, Surabaya : Universitas Teknologi Surabaya.

[29] Tarigan, Arifin Faisal. (2008). Pengaruh Karakteristik Individu, Pekerjaan \& Karakteristik Organisasi terhadap Kinerja Pegawai pada Badan Kepegawaian Negara Kantor regional III (BKN-Kanreg) Bandung. Tesis Magister Belum dipublikasi, Universitas Air langga, Surabaya Indonesia.

[30] Yunita Trisriani.(1999). Pengaruh Karakteristik Pekerjaan dan Pertukaran Pemimpin Anggota terhadap Pengembangan Karir karyawan di PT. Indofarma, Bekasi, Jawa Barat. Journal Kajian Bisnis, 5 (2). 25 130. 